\title{
ИСТОРИЯ ЛЕКСЕМЫ ГУСЬ В СТИЛИСТИЧЕСКОМ И ОНОМАСТИЧЕСКОМ АСПЕКТАХ
}

\section{The History of the Lexeme "Goose" in Stylistic and Onomastic Aspects}

Keywords: onomatology, linguistics, dialectology

Contact: МГОУ; bns020300@mail.ru

Орнитологические наименования всегда занимали особое место в ряду гуманитарных исследований в связи $\mathrm{c}$ необыкновенной мифологической нагруженностью образа птицы в сознании человека, его языке, культуре. Изучением лексемы гусь в стилистическом и ономасиологическом аспектах занимались Ф. Э. Абдулаева (Абдулаева 2015), Э. А. Абакарова (Абакарова 2017) и другие. В своей работе я делала акцент на употребление в народных говорах.

Целью данного исследования является представление истории лексемы гусь в русском языке, отражение ее семантики и рассмотрение стилистических особенностей. Исследование было проведено на базе материалов толковых, этимологических, исторических и диалектных словарей, а также при помощи Национального корпуса русского языка. Статья написана в результате исследований, проводимых Лабораторией палеолингвистики и региональной лексикографии под руководством А. В. Войтенко.

Гусь наделен в народных представлениях брачной символикой (символизирует жениха) и демоническими свойствами. Так у западных славян распространено поверье о нечистой силе, принимающей облик гуся. Эта птица занимает особое место и в святочной обрядности: например, у хорватов гусь ритуальное блюдо, а у русских - святочное игрище (Толстой 1995).

Гусь является лексемой индоевропейского происхождения. Это одно из древнейших названий птиц, которое появилось в результате звукоподражания. Опираясь на «Этимологический словарь славянских языков» под ред. О. Н. Трубачева, можно сделать вывод о том, что славянское * gqsь было заимствовано из германского, но в то же время против заимствования слав. * gesb, в частности 
из герм. *gans- говорит наличие - $i$-основы в слав., регулярно продолжающей древний тип на согласный; против этого говорит и древнее производное * goserb, с собственным соответствием в лат., а не герм. Таким образом, можем говорить о двух версиях происхождения лексемы гусь в русском языке: по первой - это результат звукоподражания, по второй - заимствование из германского.

В ядре семантического поля находится значение 'название водяной крупной птицы'. Далее по сходству по форме появилось значение 'северное созвездие'. В «Словаре русского языка» Д. Н. Ушакова дается определение 'самоедская одежда из оленьего меха'. Если заглянуть в словарь В. И. Даля, то и у него мы встретим это значение со следующим уточнением: 'гусь шьется из толстого и шерсистого оленьего меха, длинной рубахой, шерстью наружу, с накидным колпаком на вороту'. Так как мы можем судить о внешнем виде этой одежды лишь по описанию, остается сделать предположение, что свое название она получила по внешнему сходству гусиной шеи и колпака.

По отношению к человеку гусь употребляется с коннотацией эмоциональной неодобрительной оценки. Например: «хорош гусь!» или «гусь лапчатый». Обычно так говорят о ненадежном и плутоватом человеке. Также употребляется в значении «мошенник» или «ловкий человек». В составе устойчивых словосочетаний имеет следующие значения:

1. Гусей дразнить (разг.) - намеренно вызывать у кого-н. обиду, раздражение. Автором этого выражения является И. А. Крылов (басня «Гуси»).

2. Как с гуся вода - погов. о том, кому все проходит безнаказанно. Поговорка появилась еще в древние времена и была когда-то частью заговора от болезни ребенка. Знахарка, обливая заболевшее дитя «наговорной» водой, или родители, купая его в бане, приговаривали: «С гуся вода, а с дитяти худоба», именно так в те времена называли болезни. При этом верилось, что болезнь сбежит с ребенка, как вода с оперения здорового гуся. Перья любой водоплавающей птицы покрывает особый жир, по которому вода беспрепятственно скатывается, отсюда и пошло это сравнение в поговорке.

Еще одним значением, в котором употребляется гусь, является мясо этой птицы, а также блюдо из нее.

По сведениям «Словаря русских народных говоров» можем говорить о широкой семантической разветвленности лексемы гусь и сложности проведения границ между омонимией и многозначностью из-за трудностей, связанных с незнанием реалий. Среди них наблюдаются: 
1. Гусь как птица (гиперсема). Гусь бубейник (губейник) - большой черный гусь со светлой полосой поперек клюва. Гусь яловик - самка дикого гуся, у которой гусята не вывелись в обычную пору. Можем провести параллель с яловой коровой, т. е. не телившейся.

2. Детская игра «гуси-лебеди». Матка гонит стадо гусей в поле, и зовет их: «гуси, домой!» Зачем? «Волк за горою!» Они бегут домой, а волк сбоку перехватывает и ловит их.

3. Представление на святочное игрище; дети, покрытые дерюгою, посажены в корзину, изображают гусей; их обливают водой.

4. Рядиться гусем; надевать во время святочных игр две вывернутые шубы, брать в руки клюшку и, изображая гуся, ударять ею тихонько по ногам окружающих) значения связаны общим семантическим полем «святочная обрядность».

5. Гусь как болезнь на ногах от грязи. Соотносится с общенародным цыпки, ассоциирующиеся с курами.

6. Гусь как внутренность животного; гусак, ливер, осердье, коренец, грудной воловий потрох, духовая жила с легкими, сердцем и печенью, по сходству потрохов этих с летящим гусем.

7. Первая лошадь в упряжке цугом. Коней запрягали, передняя лошадь гусем называлась, на ей парнишка ездил, ездок. Названа по сходству с гусиным клином.

Далее речь пойдет об омонимах, которые выделяет СРНГ:

1. Гусь, -я, м. 1. 'Одежда березовских русских жителей и инородцев наподобие длинной рубашки из самой толстой длинношерстной оленьей шкуры, с пришитою назади такою же круглою шапкою; надевается в дорогу и в сильные морозы, сверх малицы и парки. Точно такая же одежда, носимая в летнее время и так же называемая, шьется из сукна'. Берез. Тобол., Опыт, 1852. Тобол., Том., Сиб., Свердл. - Одежда (какая?). Шенк. Арх., Лихтенштадт. 2. 'Верхняя летняя одежда из сукна в виде рубашки'. Берез. Тобол., 1852.

2. Гусь, -и, ж. 'Бутыль водки объемом в 1/4 ведра. Все (вино, водка) раскуплено, осталась гусь'. Возможно, получила свое название за вытянутое, как у гуся горлышко, но мы вынуждены согласиться с омонимией, так как не знаем наверняка, так же как и с названием одежды. 
Семантика развивалась, поэтому необходимо отметить ряд топонимов, который приводит А. В. Барандеев в «Кратком этимологическом топонимическом словаре».

В верхнем течении р. Гусь (лп Оки), расположен старинный центр стекольной промышленности г. Гусь-Хрустальный (Владимирская обл.). Изначально он возник как селение при фабрике по производству стекла и хрусталя, поэтому впоследствии оно стало называться Гусевская хрустальная фабрика. А в нижнем течении реки - пос. Гусь-Железный (Рязанская обл.), которое сформировался при железодельном заводе, за что и получило свое название. В отличие от древнейших городов Руси, окончательно они сформировались лишь к середине XVIII в. По своей структуре оба топонима представляют собой двухкомпонентные образования с постпозитивными определениями, четко информирующими об основном роде занятий этих жителей. Объединяет их начальная часть - название р. Гусь. Происхождения гидронима по одной из версий связывают с местом обитания крупной водоплавающей птицы.

Из всего вышесказанного делаем следующие выводы. Лексема гусь в истории русского литературного языка входит в основной корпус лексики. Гусь имеет непроизводную основу и продуктивен в словообразовании: гусенок, гусиный, гусыня, гуськом, гусятина и пр.

\section{Summary}

The article considers several variants of the origin of the lexeme "goose", the meaning of the word, which are located in the core and on the periphery of the semantic field. I analyzed the meanings from the dictionary of Russian folk dialects, which is very widely represented this lexeme. The article focuses on the participation of the "goose" lexeme in onomastics on the example of names of rivers and cities. Based on the results of my research, I concluded that the lexeme "goose" in the history of the Russian literary language is included in the main body of vocabulary. "Goose" has a non-derivative basis and is productive in word formation.

\section{Литература}

Абакарова, Э. Г. Символическая концептуализация семейных отношений в орнитоморфных символах проективного теста «Птица». Вестник Пермского университета. Философия. Психология. Соџиология. 2017 (2). 
Режим доступа: https://cyberleninka.ru/article/n/simvolicheskayakontseptualizatsiya-semeynyh-otnosheniy-v-ornitomorfnyh-simvolahproektivnogo-testa-ptitsa (2020-04-26).

Абдулаева, Ф. Э. Проявление эмотивности в семантике бионимов (на материале русского и китайского языков). Вестник НГУ. Серия: Лингвистика имежкультурная коммуникация. 2015 (4) Режим доступа: https://cyberleninka.ru/article/n/proyavlenie-emotivnosti-v-semantikebionimov-na-materiale-russkogo-i-kitayskogo-yazykov (2020-04-26).

Барандеев, А. В. Краткий этимологический топонимический словарь: Избранные топонимыл. Москва: ЛЕНАНД, 2018.

Даль, В. И. Толковый словарь живого великорусского языка. Режим доступа: http://slovardalja.net/word.php?wordid=6150 (2020-04-24).

Евгеньева, А. П. (ред.) Словарь русского языка: В 4-х т. Т. 1: А-Й. Москва: Русский язык, Полиграфресурсы, 1999. Режим доступа: http://febweb.ru/feb/mas/mas-abc/0encyc.htm (2020-04-24).

Жестков, В. Зачем дразнить гусей? О происхождении крылатых выражений. Режим доступа: https://shkolazhizni.ru/world/articles/66709/ (2020-04-24).

Кузнецов, С. А. (ред.) Большой толковый словарь. Режим доступа: http://gramota.ru/slovari/dic/?lop=x\&bts=x\&ro=x\&zar=x\&ag=x\&ab=x\&sin=x $\& l v=x \& a z=x \& p e=x \& w o r d=\%$ D0\%B3\%D1\%83\%D1\%81\%D1\%8C $\quad(2020-04-$ 24).

Словари.py. Режим доступа: http://www.slovari.ru/search.aspx?s=0\&p=3068 (202004-24).

Словарь Академии Российской. Часть 2 (Г-3). Санкт-Петербург, 1789-1794. Режим доступа: http://etymolog.ruslang.ru/doc/SAR2_G-Z.pdf (2020-04-24).

Словарь русского языка XI-XVII вв. Выпуск 4 (Г-Д). Режим доступа: http://etymolog.ruslang.ru/doc/xi-xvii_4.pdf (2020-04-24).

Словарь цеерковно-славянского и русского языка. Т. 1: А-Ж. Санкт-Петербург: Императорская Академия Наук, 1847. Режим доступа: http://elib.shpl.ru/ru/nodes/8463-t-1-a-zh-1847\#mode/inspect/page/70/zoom/4 (2020-04-24).

Срезневский, И. И. Материаль для Словаря древне-русского языка по письменным памятникам. T. 1: $A-K$. Санкт-Петербург: Типография 
Императорской Академии Наук, 1893. Режим доступа: http://etymolog.ruslang.ru/doc/sreznevskijA-D.pdf (2020-04-24).

Толстой, Н. И. (общ. ред.) Славянские древности: Этнолингвистический словарь: В 5 m. T. 1: А-Г. Москва: Международные отношения, 1995.

Ушаков, Д. Н. Режим доступа: http://ru.wikipedia.org/?oldid=10529869 (2020-0424).

Филин, Ф. П. (гл. ред.) Словарь русских народных говоров. Bыл. 7: Гона-Депеть. Ленинград: Издательство «Наука», 1972.

Шведова, Н. Ю. (общ. ред.) Русский семантический словарь. Толковый словарь, систематизированный по классам слов и значений. Москва: Азбуковник, 1998. 